\title{
Antioxidant Properties of Grapevine Leaves Obtained by Optimized Microwave Assisted Extraction
}

\author{
Elif Meltem İŞÇiMEN ${ }^{1 *} ，$ Mehmet HAYTA ${ }^{1}$
}

\begin{abstract}
In this study, the optimum microwave assisted extraction (MAE) parameters (solid/liquid ratio, time and power) determined by Box-Behnken Design (BBD) of Response Surface Methodology (RSM) for the extraction of antioxidant compounds from grapevine leaves. The BBD was used to define the effects of independent variables on Total Phenolic Content (TPC), DPPH radical scavenging activity and Trolox Equivalent Antioxidant Capacity (TEAC). Second-order polynomial model and regression analysis were used for prediction optimum point. The optimum conditions for MAE of grapevine leaves were determined as solid/liquid ratio of $30 \%$, power of $300 \mathrm{~W}$ and time of $300 \mathrm{sec}$. All of the models was found valid and significant independent variables $\left(\mathrm{R}^{2}\right)$ were found as $0.9282,0.9340$ and 0.9380 and the predicted experimental value of design $58.204 \mathrm{mg}$ GAE/ mL extract, $95.905 \%$ and $65.123 \%$ for TPC, DPPH scavenging activity and TEAC, respectively. The results of the present showed that MAE of grapevine leaves produce the extracts with a higher antioxidant values in a shorter time when compared with solvent extraction.
\end{abstract}

Keywords; Grapevine leaves, microwave, optimization, antioxidant, response surface methodology

\section{Asma Yaprağından Antioksidan Bileşiklerin Mikrodalga Destekli Ekstraksiyonunun Optimizasyonu}

Özet: Bu çalışmada, asma yaprağından antioksidan bileşiklerin ekstraksiyonu için mikrodalga destekli ekstraksiyonun parametreleri (katı/sıvı oranı, süre ve güç) yüzey yanıt yönteminin boxbehnken dizaynı (BBD) kullanılarak belirlenmiştir. BBD bağımsız değişkenlerin toplam fenolik madde içeriği(TPC), DPPH radikal süpürücü aktivite ve trolox eşdeğeri antioksidan kapasite(TEAC) üzerine etkisini belirlemek amaçlı kullanılmıştır. Asma yaprağının mikrodalga destekli ekstraksiyonu için optimum koşullar; 30g 100mL-1 katı/sıv1 oran1, 300w güç ve $300 \mathrm{~s}$ süre olarak belirlenmiştir. Modelin tümü anlamlı bulunmuş ve bağımsız değişkenlerin önemi (R2) TPC, DPPH süpürücü aktivite ve TEAC, sirasıyla 0.9282 , 0.9340 ve 0.9380 olarak ve dizaynın tahminlediği deneysel veriler ise $58.20 \mathrm{mg}$ GAE/ mL ekstrakt, $95.91 \%$ ve $65.12 \%$ olarak bulunmuştur. Sonuçlar solvent ekstraksiyonu ile karşılaştırıldığında mikrodalga destekli üretilen asma yaprağı antioksidanlarının daha düşük sürede daha yüksek değerlere sahip olduğu görülmüştür.

Anahtar Kelimeler; Asma Yaprağı, mikrodalga, optimizasyon, antioksidan

ORCID ID (Yazar sirasına göre)

0000-0002-9849-6352, 0000-0001-6239-8630

\footnotetext{
${ }^{1}$ Yayın Kuruluna Geliş Tarihi: 27.11.2020

Kabul Tarihi: 04.02.2021

${ }^{1}$ Erciyes Üniversitesi, Mühendislik Fakültesi, Gıda Mühendisliği Bölümü, Kayseri, Türkiye

*E-posta: eliferen@erciyes.edu.tr
} 


\section{Antioxidant Properties of Grapevine Leaves Obtained by Optimized Microwave Assisted Extraction}

\section{Introduction}

Grape is one of the most farmed products worldwide, grape production has reached over 77 MT in 2019 (FAOSTAT, 2021) and grapevine leaves are the byproducts of wine making industry (Harb at al., 2015). Many studies have shown that grapevine leaves contain health beneficial bioactive phenolic compounds (Anđelković et al., 2015; Farhadi et al., 2016). Grapevine leaves have traditionally been used a natural treatment for hypertension, hypoglycemia, diarrhea, chronic venous insufficiency and inflammatory disorder (Orhan et al., 2009)

Emerging extraction techniques such as MAE have recently been investigated as an alternative to the conventional extraction process. It is faster than solvent extraction techniques for heating solvent (Mohan at al., 2013). Microwave heating can increase of internal pressure of the cell thus disrupt plant cell wall structure (Chen and Spiro, 1995). The phenolics and phytosterols have been extracted by the use of MAE (Mustapa, Martin, Mato, and Cocero, 2015; Roselló-Soto et al k., 2015), resulting in high extraction yield, short extraction time, and less consumption of extraction solvent (Dahmoune et al., 2015). Apparently, extraction parameters might alter the characteristics of final product. For example, it has been reported that the increase in microwave power provide faster solvent penetration thus higher bioactive component extraction (Yan et al, 2010).

Efficient MAE of bioactive compounds from different materials requires optimization of extraction parameters such as power, time, solid/liquid ratio and temperature. The RSM is an effective tool for the determination of optimum extraction conditions (Box and Wilson., 1951) and has been used in various processes (Bezerra et al., 2008; Sharmila et al., 2013; Wu et al., 2015).

Although several investigations have been performed for the extraction of bioactive compounds from grapevine leaves, no study has been available on the optimization of MAE of bioactive compounds from grapevine leaves. For this reason, in this study, it was aimed to determine the optimum parameters for MAE of antioxidant compounds from grapevine leaves.

\section{Materials and Methods \\ Materials}

Grapevine leaves were collected from Kayseri (Kayseri, Turkey). The leaves were gathered in spring and they were dried in room conditions in the sunless environment. Dried leaves were ground and stored at $-20{ }^{\circ} \mathrm{C}$. Sodium phosphate dibasic $\left(\mathrm{Na}_{2} \mathrm{HPO}_{4}\right)$ (10028-24-7) and sodium phosphate monobasic $\left(\mathrm{NaH}_{2} \mathrm{PO}_{4}\right)$ (7558-80-7) were purchased from Merck and Carlo Erba, respectively. 2,2-diphenyl-1-picrylhydrazyl (DPPH) (D913-2) and 2,2'-azinobis (3ethylbenzothiazoline 6-sulfonate) (ABTS) (A1888-1) were purchased from SigmaAldrich.

\section{Methods \\ Microwave Assisted Extraction}

The MAE was carried out by microwave digestion system (Mars 6, CEM, USA) operating at maximum power of $1800 \mathrm{~W}$ power and $59 \mathrm{~min}$ of treatment time. Samples were prepared in vessels using solid/liquid ratio, microwave application time and power determined by RSM and then vessels were placed in microwave system. Microwave treated samples were centrifuged at $9000 \mathrm{rpm}$ for $15 \mathrm{~min}$ at $25^{\circ} \mathrm{C}$ and were filtered through filter paper and supernatants were collected then stored at $-18^{\circ} \mathrm{C}$.

\section{Experimental Design}

BBD of RSM (Design Expert, Trial Version 7, Stat-Ease Inc., Minneapolis, MN) was used to determine the optimum levels of the three independent variables $\left(\mathrm{X}_{1}\right.$, microwave extraction ratio; $\mathrm{X}_{2}$, microwave extraction time; $\mathrm{X}_{3}$, microwave extraction power) and three levels $(-1,0,+1)$ were evaluated according to optimum combinations of TPC, DPPH radical scavenging activity and TEAC. The experimental parameters for BBD were given in Table 1.

The ratio of solid to solvent varied from 4 to 30 $\mathrm{g} / \mathrm{mL}$, extraction time from 60 to $300 \mathrm{sec}$ and microwave power from 50 to $300 \mathrm{~W}$. All the 


\section{Antioxidant Properties of Grapevine Leaves Obtained by Optimized Microwave Assisted Extraction}

ranges for the parameters were selected based on the literature and the preliminary experimental work. The range of variables and their levels were shown in Table 2.

Polynomial second degree model was used for evaluated independent variables X1, X2 and X3 for TPC, DPPH radical scavenging activity and TEAC, respectively.

$$
Y=\beta_{0}+\sum \beta_{\mathrm{i}} X_{\mathrm{i}}+\sum \beta_{\mathrm{ii}} X_{\mathrm{i}}^{2}+\sum \beta_{\mathrm{ij}} X_{\mathrm{i}} X_{\mathrm{j}}
$$

Predicted response $\mathrm{Y}$, the fixed response at central point is $\beta 0$, the linear, quadratic and interaction coefficients are $\beta \mathrm{i}, \beta \mathrm{ii}$ and $\beta \mathrm{ij}$, respectively. the levels of the independent variables are $\mathrm{Xi}$ and $\mathrm{Xj}$.

\section{Classical Solvent Extraction}

Classical solvent extraction method was used for determined effectiveness of MAE according to classical methods. For this reason, 30\% (determined optimum ratio) sample of grapevine leaves were weighed. Prepared samples with distilled water were waited on magnetic stirrer (KS 4000i, IKA,Germany) for $2 \mathrm{~h}$. After extraction process, samples were centrifuged at $9000 \mathrm{rpm}$ for $15 \mathrm{~min}$ at $25{ }^{\circ} \mathrm{C}$ and were filtered through filter paper and supernatants were collected. TPC, DPPH scavenging activity and TEAC analysis were done and the results were compared with results of MAE extracts.

\section{Total Phenolic Content (TPC)}

Folin-Ciocalteu colorimetric method was used for TPC. Folin-Ciocalteu reagent was diluted ten times with distilled water. $\mathrm{Na}_{2} \mathrm{CO}_{3}(\% 20)$ was prepared with distilled water. Extract of sample $(30 \mu \mathrm{L})$, diluted Folin-Ciocalteu reagent $(150 \mu \mathrm{L})$ and $\mathrm{Na}_{2} \mathrm{CO}_{3}(120 \mu \mathrm{L})$ were added to microreader (Multiscan FC, Tehrmo Fisher, USA) plate. The absorbance was determined by microreader at $750 \mathrm{~nm}$ after $60 \mathrm{~min}$ incubation. TPC was expressed as mg gallic acid equivalent (GAE)/mL extract by the calibration curve generated with GA (Sağdıç et al. 2013).

\section{DPPH Radical Scavenging Activity}

The scavenging activity of samples for the radical 2,2-diphenyl-1-picrylhydrazyl (DPPH) was determined as described by Orhan et al.,(2007). with some modifications. DPPH radical solution was prepared with ethanol. 30 $\mu \mathrm{L}$ grapevine leaf extract and $270 \mu \mathrm{L}$ DPPH solution were added in microreader plate and microreader was set $5 \mathrm{~min}$ shake and $55 \mathrm{~min}$ wait at room temperature in the dark thereafter absorbance was measured at $520 \mathrm{~nm}$ (Multiscan FC, Tehrmo Fisher, USA). Following equation was used for calculate the \% scavenging activity.

DPPH $(\%)=\left[1-\frac{\text { Absorbance of sample }}{\text { Absorbance of control }}\right] \times 100$

\section{Trolox Equivalent Antioxidant Capacity (TEAC)}

TEAC assay was performed according to (Carbone and Mencarelli, 2015). $7 \mathrm{mM}$ ABTS (2,2'-Azino-bis(3-ethylbenzothiazoline-6sulfonic acid) diammonium salt) was weighed in $25 \mathrm{~mL}$ volumetric flask and $5 \mathrm{~mL}$ of 12.25 $\mathrm{mM}$ potassium persulfate solution was prepared and added on ABTS then volume was made up $25 \mathrm{~mL}$ with distilled water. This ABTS solution was incubated in the dark 12-16 h. Phosphate buffer solution (containing $100 \mathrm{mM}$ phosphate and $150 \mathrm{mM} \mathrm{NaCl}$ ) which was used for diluting the sample and ABTS solution was prepared at $\mathrm{pH}$ 7.4. $60 \mu \mathrm{L}$ of sample and $2 \mathrm{~mL}$ of ABTS solution were added in spectrophotometer tube and incubated for $6 \mathrm{~min}$ then the absorbance value was measured at $734 \mathrm{~nm}$. The following equation was used for calculation of \% inhibition. Trolox curve was prepared at different concentrations ( $\left.\begin{array}{llll}0.5 & -2.0 & \mathrm{mM}\end{array}\right)$ for calibration curve.

Inhibition (\%=) $\left[\right.$ Absorbance of ABTS- $\left.\frac{\text { Absorbance of sample }}{\text { Absorbance of ABTS }}\right] \times 100$

\section{Statistical Analysis}

The analysis of variance (ANOVA) was used for optimization procedure. Parameters of the ANOVA; lack of fit, coefficient of determination $\left(\mathrm{R}^{2}\right)$ and $\mathrm{F}$-test were used to 


\section{Antioxidant Properties of Grapevine Leaves Obtained by Optimized Microwave Assisted Extraction}

evaluate the model adequacy. The model was fitted by quadratic regressions and response surface plots were obtained for three responses. The statistical tests were employed for the checking of the statistical significance with confidence level of $95.0 \%$.

\section{Results and Discussion \\ Fitting the models}

Experimental design of microwave extraction methods such as microwave power, extraction time and temperature, solvent composition and solid to liquid ratio have been reported (Amutha Gnana Arasi ve ark.,2016; Heleno ve ark., 2016; Lefsih at al.,2017). The results of the present study for the TPC, DPPH radical scavenging activity and TEAC were presented in Table 2.

The quadratic model of ANOVA of TPC, DPPH radical scavenging activity and TEAC for MAE optimization of grapevine leaves were listed in Table 3, 4 and 5. The result indicated that extraction ratio and time for TPC and $\mathrm{DPPH}$, extraction ratio time and power for TEAC have a significant $(\mathrm{p}<0.05)$ effect on extraction yield.
The validity of model was tested by lack of fit test the value was found not significant $(p>0.05)$ for three responses. The model fitted the experimentel data. The $\mathrm{R}^{2}$ values of TPC, DPPH radical sacavenging activity and TEAC were found $0.928,0.934$ and 0.938 respectively. The models were found that significant $(p<0.05)$ for three responses (Table 3 ).

The optimum conditions of MAE from grapevine leaves for highest antioxidant yield were determined as \%30 (solid/liquid ratio), $300 \mathrm{~W}$ (power) and $202.07 \mathrm{sec}$ (time).

Variety, the cultivation region and conditions and harvest season affects antioxidant properties of grapevine leaves (Katalinić et al., 2009). Antioxidant properties of food system are important for providing health benefits. Therefore various methods have been used to determine the antioxidant properties of food system (Madhujith and Shahidi, 2009).

In this study, TPC, DPPH radical scavenging activity and TEAC assays were used for

Table 1. Independent variables and their levels in Box-Behnken Design (BBD)

\begin{tabular}{|l|c|c|c|c|}
\hline Independent variable & \multirow{2}{*}{ symbols } & \multicolumn{3}{|c|}{ levels } \\
\cline { 3 - 5 } & & -1 & 0 & 1 \\
\hline Solid/liquid ratio $(\mathrm{g} / 100 \mathrm{~mL})$ & $\mathrm{X}_{1}$ & 4 & 17 & 30 \\
\hline Extraction time $(\mathrm{min})$ & $\mathrm{X}_{2}$ & 60 & 175 & 300 \\
\hline Power $(\mathrm{W})$ & $\mathrm{X}_{3}$ & 50 & 170 & 300 \\
\hline
\end{tabular}

Table 2. BBD and measured responses used in experimental design for RSM

\begin{tabular}{|c|c|c|c|c|c|c|}
\hline Run & $\begin{array}{c}\text { Factor } 1 \\
\text { A: Ratio } \\
(\%)\end{array}$ & $\begin{array}{l}\text { Factor } 2 \\
\text { B:Time } \\
\text { (minute) }\end{array}$ & $\begin{array}{l}\text { Factor } 3 \\
\text { C:Power } \\
\text { (W) }\end{array}$ & $\begin{array}{c}\text { R1: } \\
\text { TPC } \\
\text { (mg } \\
\text { GAE/mL } \\
\text { extract) }\end{array}$ & $\begin{array}{c}\text { R2: } \\
\text { DPPH } \\
(\%, 100 \mu \mathrm{L} \\
\text { extract })\end{array}$ & $\begin{array}{c}\text { R3: } \\
\text { TEAC } \\
(\%, 10 \mu \mathrm{L} \\
\text { extract })\end{array}$ \\
\hline 1 & 30.00 & 300.00 & 170.00 & 55.09 & 93.95 & 60.54 \\
\hline 2 & 4.00 & 300.00 & 170.00 & 16.19 & 46.74 & 20.76 \\
\hline
\end{tabular}




\section{Antioxidant Properties of Grapevine Leaves Obtained by Optimized Microwave Assisted Extraction}

\begin{tabular}{|c|c|c|c|c|c|c|}
\hline 3 & 4.00 & 180.00 & 300.00 & 17.07 & 46.86 & 19.41 \\
\hline 4 & 17.00 & 180.00 & 170.00 & 22.29 & 48.28 & 23.01 \\
\hline 5 & 30.00 & 60.00 & 170.00 & 48.39 & 80.00 & 43.82 \\
\hline 6 & 17.00 & 180.00 & 170.00 & 28.63 & 55.88 & 30.26 \\
\hline 7 & 17.00 & 180.00 & 170.00 & 25.99 & 52.01 & 26.91 \\
\hline 8 & 30.00 & 180.00 & 50.00 & 35.07 & 68.62 & 34.41 \\
\hline 9 & 17.00 & 300.00 & 300.00 & 44.24 & 91.80 & 51.14 \\
\hline 10 & 30.00 & 180.00 & 300.00 & 58.52 & 95.91 & 65.35 \\
\hline 11 & 4.00 & 60.00 & 170.00 & 10.26 & 26.24 & 13.99 \\
\hline 12 & 17.00 & 180.00 & 170.00 & 18.57 & 42.61 & 21.19 \\
\hline 13 & 17.00 & 180.00 & 170.00 & 22.74 & 48.69 & 27.41 \\
\hline 14 & 17.00 & 300.00 & 50.00 & 27.69 & 58.25 & 31.59 \\
\hline 15 & 17.00 & 60.00 & 50.00 & 26.50 & 55.14 & 27.26 \\
\hline 16 & 4.00 & 60.00 & 50.00 & 9.42 & 23.04 & 13.36 \\
\hline 17 & 17.00 & 60.00 & 300.00 & 10.41 & 25.80 & 13.58 \\
\hline
\end{tabular}

assessing the antioxidant properties of In optimization researches, second-order grapevine leaves after MAE. The use MAE may provide increased extraction yield of antioxidant compounds from different materials in shorter time. It was reported that application of microwave power causes in rapid the cell wall disruption and as a result more component can obtained (Wang and Weller, 2006). The mechanism behind the beneficial effect of the microwave power is thought to be result from increase in solvent temperature and solubility and therefore in the mass transfer rate (Hemwimon at al., 2007).

\section{Response surface analysis of TPC}

The results of ANOVA showed that the model of TPC was significant $(p<0.05)$ and coefficient of determination $\left(\mathrm{R}^{2}\right)$ was 0.9282 (Table 3 ). The $\mathrm{R}^{2}$ values ranges from 0 to 1 and known that it should be close to 1 for the model to be more accurate (Badwaik et al., 2012). polynomial model has widely been used (Anderson-Cook et al., 2009)The relationship between the independent variables and response of TPC of current study was described by a mathematical model (Eq 3.1).

Eq. 3.1. Equation of extraction parameters of TPC optimization analysis;

$\mathrm{R} 1=23.91+18.44 \mathrm{~A}+6.61 \mathrm{~B}+3.97 \mathrm{C}+0.74 \mathrm{AB}+3.2$ $5 \mathrm{AC}+7.70 \mathrm{BC}+5.54 \mathrm{~A}^{2}+2.70 \mathrm{~B}^{2}+0.097 \mathrm{C}^{2}$

$\mathrm{P}$ value of model was found as 0.0030 , smaller than 0.05 . On the other hand lack of fit value was found as 0.081 . A large $F$ value and a small $p$ value shows that the model is more significant and independent variables have more effective on response (Quanhong and Caili, 2005).

Antioxidant properties and biological activity of grapevine leaves have been known due likely to 


\section{Antioxidant Properties of Grapevine Leaves Obtained by Optimized Microwave Assisted Extraction}

their contents of different types of phenolic compounds such as tannins, flavonoids, procyanidins and anthocyanins (Felicio et al., 2001; Kosar et al.,2007).

Response surface plots (3D) of total phenolic compound analysis as a function of significant interaction between factors ((A) ratio and time; (B) ratio and power; (C) time and power) were given in Figures 1a. The effects of ratio and time are presented in Figure 1a. When the time and ratio increase, response 1 (TPC value) also increase. Effect of microwave power was insignificant and ratio was significant for TPC (Figure 1aB). Figure $1 \mathrm{aC}$ demonstrated that response was highest at $300 \mathrm{~W}$.

It was seen that microwave application time $(\mathrm{p}=0.0233)$ and solid/liquid ratio were significant $(\mathrm{p}<0.0001)$ but the effect of microwave power $(0.1285)$ was insignificant for TPC of grapevine leaves (Table 3 ).

\section{Response surface analysis of DPPH radical scavenging activity}

The model of DPPH scavenging activity was found significant $(\mathrm{p}=0.0023)$ and significant independent variables $\left(\mathrm{R}^{2}\right)$ was found as 0.9340 by ANOVA. It was mean that the sample variation of $93.40 \%$ for the DPPH radical scavenging activity was attributed to the independent variables. Lack of fit value was insignificant ( $p=0.0533$ ) so that the model was found valid. The ANOVA results shows that effect of microwave application time $(\mathrm{p}=0.0034)$ and solid/liquid ratio were significant $(\mathrm{p}=0.0001)$ and microwave power $(\mathrm{p}=0.0882)$ was insignificant for DPPH scavenging activity of grapevine leaves extracts (Table 3).

Figure $1 \mathrm{~b}$ depicts that when ratio and time increased, DPPH scavenging activity (response 2 ) also increase. Figure $1 \mathrm{bA}$ and Figure $1 \mathrm{bB}$ showed that time and ratio important for response 2 but power was insignificant and maximum DPPH scavenging value was obtained at $300 \mathrm{~W}$.
The relationship between independent variables and DPPH scavenging activity was presented in the mathematical model (Eq. 3.2).

Eq. 3.2. Equation of extraction parameters of DPPH optimization analysis;

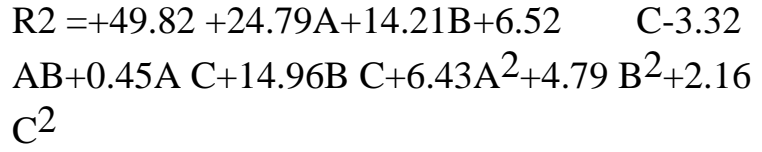

\section{Response surface analysis of TEAC}

The $\mathrm{p}$ value of model and lack of fit was found 0.0001 and 0.0793 , respectively. It was mean the model was valid according to ANOVA of TEAC analysis. It was seen that all independent variables were significant. The $\mathrm{P}$ values of application time, solid/liquid ratio and microwave power was found as 0.0043 , $<0.0001$ and 0.0452 , respectively (Table 3 ).

The mathematical model for the TEAC is given in Eq. 3.3.

Eq. 3.3. Equation of extraction parameters of total antioxidant activity optimization analysis;

$$
\begin{array}{lr}
\mathrm{R} 3 & =+26.07+17.42 \\
\mathrm{~A}+9.04 \mathrm{~B}+5.34 \mathrm{C}+1.39 \mathrm{AB}+5.64 \mathrm{~A} \quad \mathrm{C}+7.57 & \\
\mathrm{BC}+5.40 \mathrm{~A}^{2}+2.81 \mathrm{~B}^{2}+1.29 \mathrm{C}^{2} &
\end{array}
$$

The highest TEAC value was obtained when solid/liquid ratio set to $30 \%$ (Figure 1cA). When the ratio increased, an increase occurs in the response (TEAC). Figure $1 \mathrm{cB}$ shows the ratio more effective from microwave power on TEAC. Figure $3 \mathrm{C}$ shows the effect of time and power on TEAC. The highest TEAC value was obtained by the application of microwave power of $300 \mathrm{~W}$ (Figure 1cC).

\section{Comparison of Extraction Methods}

The optimum microwave condition was determined as $30 \%$ solid/liquid ratio, $300 \mathrm{sec}$ and $300 \mathrm{~W}$ microwave power for highest antioxidant compound extraction from grapevine leaves. 
Table 3. Quadratic model of ANOVA of TPC, DPPH scavenging activity and TEAC for MAE optimization

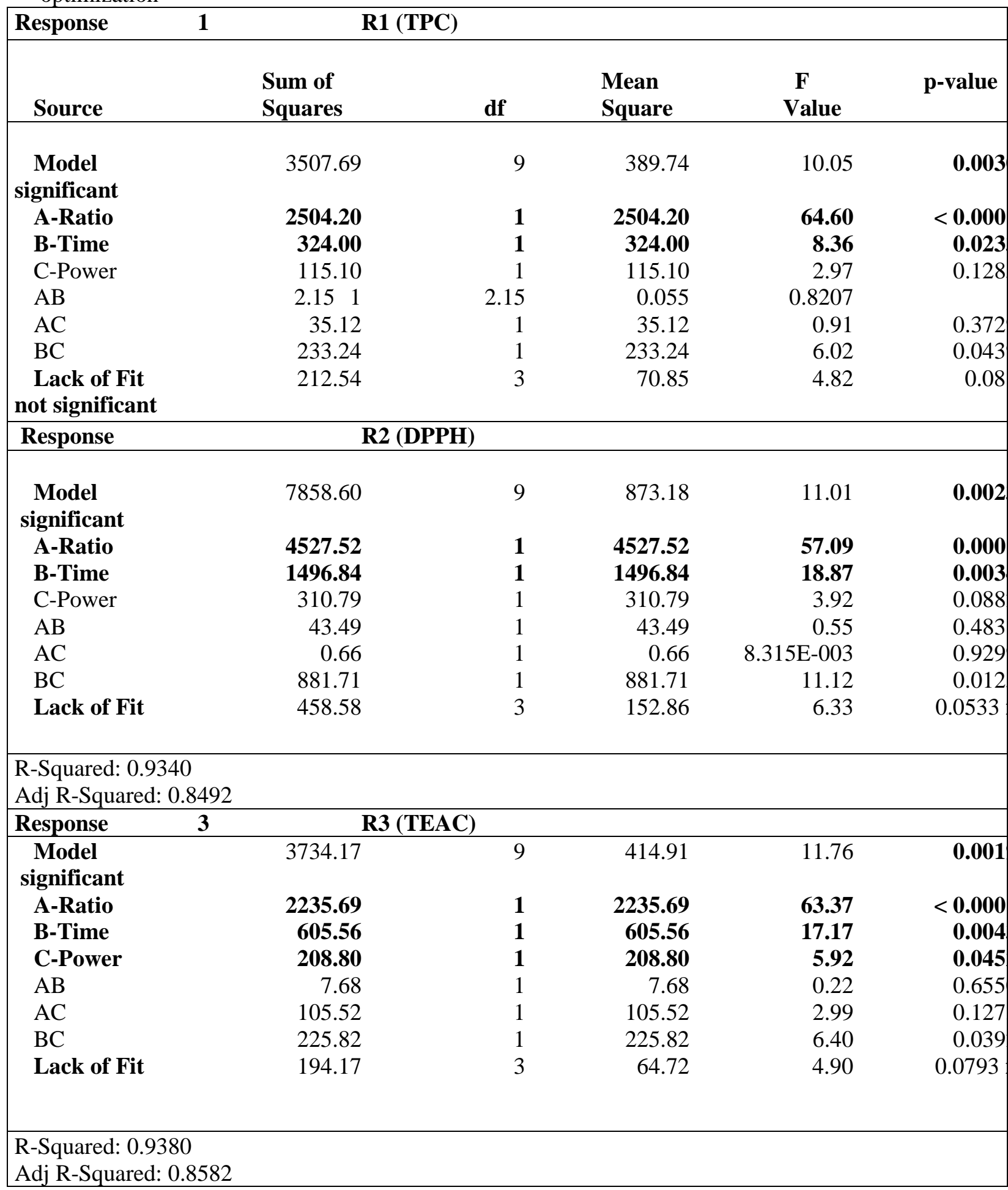




\section{Antioxidant Properties of Grapevine Leaves Obtained by Optimized Microwave Assisted Extraction}

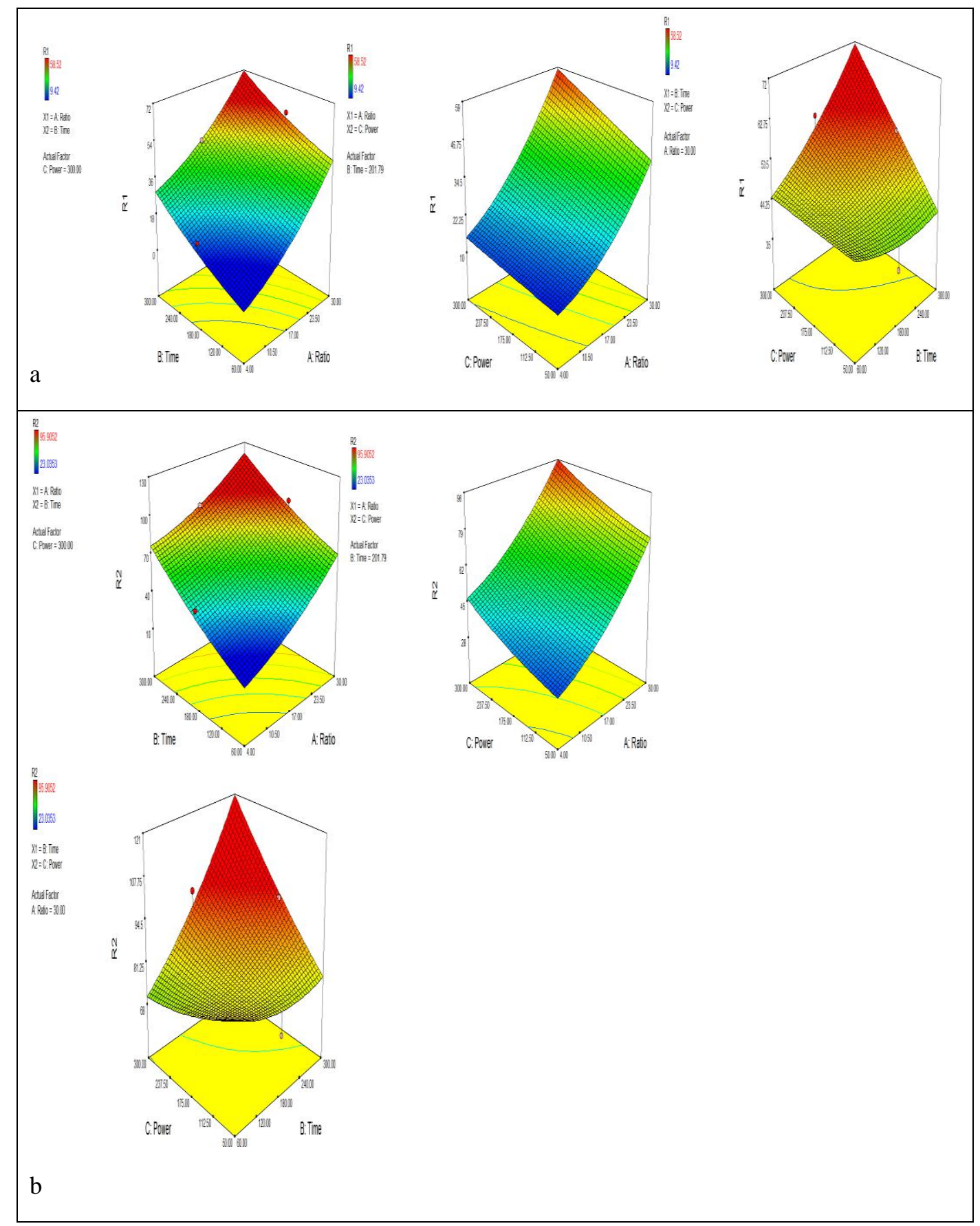

Figure 1. Response surface plots (3D) of a.TPC, b. DPPH scavenging activity anc c. TEAC, as a function of significant interaction between factors; (A) ratio and time; (B) ratio and power; (C) time and power.

A solvent extraction was also carried out to compare the effectiveness of optimized MAE. For the classical solvent extraction $30 \%$ solid/liquid ratio and $2 \mathrm{~h}$ extraction time were selected and optimized conditions (30\%, 300 sec and $300 \mathrm{~W}$ ) were used for MAE of antioxidant compounds from grapevine leaves. The TPC, DPPH scavenging activity and TEAC 


\section{Antioxidant Properties of Grapevine Leaves Obtained by Optimized Microwave Assisted Extraction}

analysis were employed for the comparison of the extracts. The TPC, DPPH scavenging activity and TEAC values were $53.08 \mathrm{mg}$ $\mathrm{GAE} / \mathrm{mL}$ extract, $94.64 \%$ and $44.018 \%$ respectively for $300 \mathrm{sec}$. Whereas TPC, DPPH radical scavenging activity and TEAC values of solvent extraction method 39.66, 92.96\% and $31.99 \%$ respectively for $2 \mathrm{~h}$. The results demonstrated that MAE is a useful method for the effective (higher yield and shorter time) extraction of antioxidant compounds from grapevine leaves. The reason for the time saving might be due to the effect of microwave energy on moisture of cell increasing its temperature consequently the pressure on the cell wall leading to degradation and movement of the target compounds in to solvent from broken cell membrane (Dahmoune et al., 2015; Dhobi et al., 2009; Nayak et al., 2015). There have previously been claimed that MAE reduces solvent consumption, extraction time and increases yield ( Salerno et al., 2014; Sanchez-Reinoso et al., 2020; Mellinas et al., 2020).

\section{Conclusion}

BBD of RSM was used to assess the optimum condition for antioxidant extraction from grapevine leaves by MAE in this study. For this reason three independent variables (solid/liquid ratio, application time and microwave power) were used to determine highest extraction of antioxidant compound (TPC, DPPH radical scavenging activity and TEAC) from grapevine leaves. The regression coefficient obtained from ANOVA analysis in BBD were 0.9282, 0.9340 and 0.9380 for the TPC, DPPH radical scavenging activity and TEAC, respectively. The optimum conditions were determined as $30 \%$ solid/ liquid ratio, $202.07 \mathrm{sec}$ extraction time and $300 \mathrm{~W}$ microwave power for MAE of antioxidant compounds from grapevine leaves. Comparison study was also performed between MAE and classical solvent extraction technique. It was confirmed that MAE is shorter than solvent extraction for the same extraction yield. The conventional techniques are less effective than novel technologies such as MAE therefore developing technologies seems logical alternatives for the extraction of bioactive compounds from plant materials. Considering the grapevine leaves as industrial waste, it is likely to obtain antioxidant compounds from grapevine leaves by using RSM determined optimum MAE conditions.

\section{References}

Amutha Gnana Arasi, M. A. S., Gopal Rao, M., \& Bagyalakshmi, J. (2016). Optimization of microwave-assisted extraction of polysaccharide from Psidium guajava L. fruits. Int $j$ of biol macroml 91, 227-232.

Anđelković, M., Radovanović, B., Anđelković, A. M., \& Radovanović, V. (2015). Phenolic Compounds and Bioactivity of Healthy and Infected Grapevine Leaf Extracts from Red Varieties Merlot and Vranac (Vitis vinifera L.). Plant Foods for Hum Nutr 70(3), 317-323.

Anderson-Cook, C. M., Borror, C. M., \& Montgomery, D. C. (2009). Response surface design evaluation and comparison. J Stat Plan Infer 139(2), 629-641.

Badwaik, L. S., Prasad, K., \& Deka, S. C. . (2012). Optimization of extraction conditions by response surface methodology for preparing partially defatted peanut Int Food Res J 119, 341-346.

Bezerra, M. A., Santelli, R. E., Oliveira, E. P., Villar, L. S., \& Escaleira, L. A. (2008). Response surface methodology (RSM) as a tool for optimization in analytical chemistry. Talanta, 76(5), 965-977.

Box, G. E. P., Wilson, K. B. . (1951). On the experimental attainment of optimum conditions. J R Stat Soc, 13, 1-45.

Carbone, K., \& Mencarelli, F. (2015). Influence of short-term postharvest ozone treatments in nitrogen or air atmosphere on the metabolic response of white wine grapes. Food and Bioprocess Tech, 8(8), 1739-1749.

Chen, S. S., \& Spiro, M. (1995). Kinetics of microwave extraction of rosemary leaves in hexane, ethanol and a hexane+ ethanol mixture. Flavour Fragr j 10(2), 101-112. 


\section{Antioxidant Properties of Grapevine Leaves Obtained by Optimized Microwave Assisted Extraction}

Dahmoune, F., Nayak, B., Moussi, K., Remini, H., \& Madani, K. (2015). Optimization of microwave-assisted extraction of polyphenols from Myrtus communis L. leaves. Food chem, 166, 585-595.

FAOSTAT. (2021). Food and Agriculture Organization of the United Nations Statistics

Division. http://www.fao.org/faostat/en/\#data/QC /visualize(03.02.2021) .

Farhadi, K., Esmaeilzadeh, F., Hatami, M., Forough, M., \& Molaie, R. (2016). Determination of phenolic compounds content and antioxidant activity in skin, pulp, seed, cane and leaf of five native grape cultivars in West Azerbaijan province, Iran. Food chem, 199, 847855.

Felicio, J., Santos, R. d. S., \& Gonçalez, E. (2001). Chemical constituents from Vitis vinifera (Vitaceae). Arquivos do Instituto Biológico, 68(1), 47-50.

Harb, J., Alseekh, S., Tohge, T., \& Fernie, A. R. (2015). Profiling of primary metabolites and flavonols in leaves of two table grape varieties collected from semiarid and temperate regions. Phytochemistry, 117, 444-455.

Heleno, S. A., Prieto, M., Barros, L., Rodrigues, A., Barreiro, M. F., \& Ferreira, I. C. (2016). Optimization of microwave-assisted extraction of ergosterol from Agaricus bisporus L. by-products using response surface methodology. Food and Bioprod Processing, 100, 25-35.

Hemwimon, S., Pavasant, P., \& Shotipruk, A. (2007). Microwave-assisted extraction of antioxidative anthraquinones from roots of Morinda citrifolia. Sep Purif Technol 54(1), 44-50.

Katalinić, V., Generalić, I., Skroza, D., Ljubenkov, I., Teskera, A., Konta, I., \& Boban, M. (2009). Insight in the phenolic composition and antioxidative properties of Vitis vinifera leaves extracts. Croatian J Food Sci Technol 1(2), 7-15.

Kosar, M., Küpeli, E., Malyer, H., Uylaser, V., Türkben, C., \& Baser, K. H. C. (2007).
Effect of brining on biological activity of leaves of Vitis vinifera L.(cv. Sultani Cekirdeksiz) from Turkey. J agric food chem 55(11), 4596-4603.

Lefsih, K., Giacomazza, D., Dahmoune, F., Mangione, M. R., Bulone, D., San Biagio, P. L., . . . Madani, K. (2017). Pectin from Opuntia ficus indica: Optimization of microwave-assisted extraction and preliminary characterization. Food chem, 221, 9199.

doi:http://dx.doi.org/10.1016/j.foodche $\underline{\text { m.2016.10.073 }}$

Madhujith, T., \& Shahidi, F. (2009). Antioxidant potential of barley as affected by alkaline hydrolysis and release of insoluble-bound phenolics. Food Chem, 117(4), 615-620. doi:http://dx.doi.org/10.1016/j.foodche $\underline{\mathrm{m} .2009 .04 .055}$

Mellinas, A.C., Jiménez, A., Garrigós, M.C. (2020). Optimization of microwaveassisted extraction of cocoa bean shell waste and evaluation of its antioxidant, physicochemical and functional properties.LWT.127,109361.

Mohan, M., Khanam, S., \& Shivananda, B. (2013). Optimization of microwave assisted extraction of andrographolide from Andrographis paniculata and its comparison with refluxation extraction method. J Pharmacogn Phytochem 2(1), 342-348.

Mustapa, A. N., Martin, Á., Mato, R. B., \& Cocero, M. J. (2015). Extraction of phytocompounds from the medicinal plant Clinacanthus nutans Lindau by microwave-assisted extraction and supercritical carbon dioxide extraction. Ind Crops Prod 74, 83-94.

Nayak, B., Dahmoune, F., Moussi, K., Remini, H., Dairi, S., Aoun, O., \& Khodir, M. (2015). Comparison of microwave, ultrasound and accelerated-assisted solvent extraction for recovery of polyphenols from Citrus sinensis peels. Food chem 187, 507-516. 


\section{Antioxidant Properties of Grapevine Leaves Obtained by Optimized Microwave Assisted Extraction}

Orhan, N., Aslan, M.,, Orhan, D.D., Ergun, F., Yesilada, E. (2006). In vivo assessment of antidiabetic and antioxidant activities of grapeleaves (Vitis vinifera) in diabetic rats. J. Ethnopharmacol. 108,280-286.

Orhan, I., Kartal, M., Naz, Q., Ejaz, A., Yilmaz, G., Kan, Y., et al. (2007)Antioxidant and anticholinesterase evaluation of selected Turkish Salvia species. Food Chem. 103, 1247-1254.

Quanhong, L., \& Caili, F. (2005). Application of response surface methodology for extraction optimization of germinant pumpkin seeds protein. Food Chem 92(4), 701-706. doi:http://dx.doi.org/10.1016/j.foodche m.2004.08.042

Roselló-Soto, E., Koubaa, M., Moubarik, A., Lopes, R. P., Saraiva, J. A., Boussetta, N., . . . Barba, F. J. (2015). Emerging opportunities for the effective valorization of wastes and by-products generated during olive oil production process: Non-conventional methods for the recovery of high-added value compounds. Trends Food Sci Technol 45(2), 296-310.

Sağdiç, O., Silici, S.,Ekici, L. (2013).Evaluation of the phenolic content and antiradical, antioxidant, antimicrobial activities of different floral sources of honey. Int $\mathrm{J}$ Food Prop, 16, 658-666.

Salerno, L., Modica, M. N., Pittalà, V., Romeo, G., Siracusa, M. A., Di Giacomo, C., Acquaviva, R. (2014). Antioxidant activity and phenolic content of microwave-assisted Solanum melongena extracts. Sci World J 2014(2014), 6.

Sanchez-Reinoso, Z., Mora-Adames, W.I., Fuenmayor, C.A., Darghan-Contreras, A.E., Gardana, C., Gutiérrez, L.-F. (2020). Microwave-assisted extraction of phenolic compounds from Sacha Inchi shell: Optimization, physicochemical properties and evaluation of their antioxidant activity.
Chem Eng Processing - Process Intensification. 153.

Sharmila, G., Nidhi, B., \& Muthukumaran, C. . (2013). Sequential statistical optimization of red pigment production by Monascus purpureus (MTCC 369) using potato powder Ind Crops and Prod 44, 158-164.

Wang, L., \& Weller, C. L. (2006). Recent advances in extraction of nutraceuticals from plants. Trends Food Sci Techno 17(6), 300-312.

Wu, J., Yu, D., Sun, H., Zhang, Y., Zhang, W., Meng, F., \& Du, X. . (2015). Optimizing the extraction of anti-tumor alkaloids from the stem of Berberis amurensis by response surface methodology. Ind Crops and Prod, 69, 68-75.

Yan, M.-M., Liu, W., Fu, Y.-J., Zu, Y.-G., Chen, C.-Y., \& Luo, M. (2010). Optimisation of the microwave-assisted extraction process for four main astragalosides in Radix Astragali. Food chem 119(4), 1663-1670. 
Antioxidant Properties of Grapevine Leaves Obtained by Optimized Microwave Assisted Extraction 